\title{
A STUDY OF MAX WEBER THOUGHT ON ITS RELATION TO WORK PURPOSES AND ETHICS IN THE ISLAMIC ECONOMICS
}

\author{
Alfina Rahmatia \\ Institut Agama Islam Negeri Palangka Raya \\ rahmatiaalfina@gmail.com \\ Received : 2019-03-22 \\ ; Accepted : 2019-04-18 \\ ; Published : 2019-04-24
}

\begin{abstract}
This study seeks to expand the horizon of existing literatures on the Max Weber thought and its influence towards the Islamic economics view. This study uses library research method and web research method. It answers question about the theory of Max Weber and how its influence towards Islamic economics development, particularly in work purposes and ethics. This study compares Max Weber thought and Islamic view about economic in which the economic activity that is criticized by the work and ethic in Islam. In the end of this study shows that rationality theory from Max Weber is not in line with the Islamic economics view completely.
\end{abstract}

Keywords: Max Weber thought, Islamic economics

Sociology is a science that has gone through the process of development of philosophical thought and empirical-histories. The social phenomenon that occurred in Western Europe between the fifteenth and the eighteenth centuries was a background that greatly influenced the development of sociology. Sociology is considered a science that has a pluralistic paradigm that is caused by the complexity of existing problems in society resulting in a variety of perspectives in sociology itself (Soekanto 2014).

The birth of sociology aims to understand the level of human and societal development in social life as the father of sociology Auguste Comte once put it through his Positive theory. Sociology is considered important for scientists, both social scientists and other scientists in studying the level of social life of society that developed from time to time (Nugroho 2016).

DOI : 10.23971/tf.v3i1.1228

Transformatif (Journal Islamic Studies), 3 (1), Hal 19-41

Copyright $\odot$ year by Transformatif, p-ISSN 2580-7056; e-ISSN 2580-7064 
Each of these classical sociologists has their own leading theories with different points of view. There are those who propose new theories but some have perfected theories that have existed before.

The development of sociology cannot be attributed to the services of other sociologists, such as Auguste Comte, Emile Dukheim, Karl Max, Ferdinan Tonnis, Max Weber, and a range of other sociological figures. They are considered the most meritorious in the development of sociology because their minds become the basis of reference in understanding the concept of social life of society.

Then, from sociology to theology, does one's understanding of theology affect economic activity? This fundamental question has been widely discussed by experts for an empirical explanation through research. The above question is also important to answer in an attempt to assert that religion is not merely an affirmation of identity. A true understanding of religion is necessary. The size of course with the method of science (religion) itself. In the context of this study, an adequate description of the realization and influence of Max Weber's understanding of the economy is necessary to prove that religion is functional in one's self. Does religion serve as a guide to life?

After believing that one's understanding affects economic activity especially on work purposes, then the critical question we can ask is whether the Islam we have been studying has been sufficient to sustain economic development? If not, what understanding is conducive to sustaining the growth and development of Islamic economics?

In this context Max Weber's position is quite important. Not only to be examined, but also to be criticized. Thus, the issues to be studied in this paper are about Max Weber's brief biography and his thinking and the relevance of his thinking to the development of Islamic economics. In order to know Max Weber and his position in religious studies. 


\section{THE OVERVIEW OF MAX WEBER'S BIOGRAPHY}

On 21 April 1864, Max Weber was born in Erfurt, Germany. He came from a prominent family of the middle class in the political circles of the National Liberal Party in the Bismark. Max Weber was born from two different parental characters and it influenced Weber's intellectual and psychological orientation. Max Weber's father was a capable lawyer and city counselor, coming from a family of linen merchants and textile producers in the western Germany. Max Weber's mother is a devout Calvinist, a woman who tries to live in an ascetic life without the pleasure from her husband desires because Max Weber's father is a man who likes a pleasures in the world. Thus, Max Weber's intellectual orientation and psychological development were influenced by his parents (Noorkholis 2006).

When Max Weber accepted as professor of economics at the University of Freiburg in 1894, it became his first star in academic life. In 1896, his zeal in this work led him as professor of economics at Heidelberg. His father died n 1897, when developing an academic career after a terrible fight and kicked out by Max Weber from home. This makes Max Weber felt guilty so that the physical and psychological health of undisturbed for many years. In 1899, he had to be hospitalized for several weeks. In 1903, when he delivered his first lecture within six and a half years, Max Weber was able to return to active academic life again (Crossman 2017).

In Max Weber's life and his works, there is a tension between the bureaucratic minds, as displayed by the father, with the religiosity of his mother. The insoluble tension has penetrated into Weber's The Protestant Ethic and The Spirit of Capitalism. Weber died on June 14, 1920, when he worked on his most important work of the Economy and Society (Ritzer dan Goodmman 2003).

\section{METHOD}

The data used in this study is secondary data taken from the library and internet. This study uses qualitative method in which to explore, compare and 
discuss Max Weber thought and its relation to the Islamic Economics on work pusposes and ethics.

Data analysis technique in qualitative research through a procedure that has done by many expert of qualitative researchers. The procedure is undergoing data collection, data input, data analysis, conclusion and verification, and ending with the form of the findings in narrative form (Herdiansyah 2010). So, this research will contain enormous narative form to be discussed.

\section{RESULTS}

\section{Max Weber Rationality Theory}

Rationality is one of the theories put forward by Weber. In initiating this theory, Weber affected by social and cultural life of Western society at that time in which Western society socio-cultural conditions, especially in terms of thinking began to shift from non-rational thinking to the rational thinking. This is seen by Weber as the early phenomenon of modernity, so Weber analyzed it (modernity) through the theory of Rationality. In addition to Weber as the sociologist who lived in this era one of them is Karl Marx. In contrast to Weber, Karl Marx modernity analization uses capitalist theory. But according to Weber capitalism cannot be used as a concept or keyword of modernity, because he thinks capitalism is only one aspect of rationality. Weber considers that modernization is an extension of rationality in many aspects of people's lives (Santoso dan dkk 2007).

The development of rationalization of society is also related to the institutionalization of science and technology into all aspects of life. This is probably because the scientific and technological achievements shown in the modern society have been able to offer and meet the various needs of society. This fact is supported by the influential positivism at that the time that is the belief in the ability of natural sciences to deal with various problems in society. So, rationalization in Weber's sense is the process of widespread use of rationality into all aspects of people's lives. 
Rationality comes from the word "ratio" which refers to Ancient Greek, which means the cognitive ability to separate between right and wrong from the exist and in reality. According to Max Weber theory, there are two types of human rationality generally, namely the objective of rationality (Zwekrationalitaet) and the value of rationality (Wetrationalitaet) (Ibid):

1. The objective of rationality is the rationality that causes a person or group of people in an action to be oriented toward the goal of action, how to achieve it and its consequences. This characteristic of rationality is formal, because it is only concerned with purpose and ignores value judgments.

2. The value of rationality is a rationality that takes into consideration the values or norms that justify or condemn a particular way to achieve a goal. This rationality emphasizes the awareness of aesthetic, ethical, and religious values. This characteristic of value rationality is substantive, because the person acting with this rationality attaches to his rationality commitment to personalized value. In reality, these two types of rationality are often mixed up in which there is a dominance of rationality of purpose over the rationality of values, and vice versa.

In addition to these two types, some sociologists interpret that Weber actually triggered the type of rationality into three parts: instrumental rationality, juridical and cognitive or scientific ratios. These three ratios (according to some sociologists, especially Ross Poole) are not explicitly expressed by Weber, but these three types of ratios are in the teachings of Weber's rationality (Kalberg 1980):

1. The instrumental ratio is the most dominant form of ratios embodied in a capitalist market. This ratio emphasizes efficiency and effectiveness in achieving specific goals. In applying this ratio, there are several things to do. First, the supposition of a destination for alternative routes. Secondly, the presupposition of an actor who considers himself free to choose those routes. Because of its emphasis on efficiency, this ratio prefers quantitative or quantifiable results. 
2. Juridical ratio is a ratio that refers to a form of rationality that is objectively realized in the field of law and bureaucracy. This rationality emphasizes the principle of consistency, rather than the principle of efficiency (instrumental ratio). This ratio is not uncommon to experience cons with other ratios, for example is the instrumental ratio. An extreme example is when the use of bribes to launch a project or business. According to this ratio, the act is contrary to morals and not true, but according to instrumental ratios, this action is fine as long as it makes it easier to get something. The juridical ratio in a society functions as a social morality which must be obeyed to limit power. But in capitalist society, this ratio is less dominant than the instrumental ratio.

The cognitive ratio is the ratio that explains that the objective of the ratio is knowledge in order to seek the truth that corresponds to the world. The manifestation of this rationality is found in modern educational or research institutions. The application of this ratio is that truth is merely confined to truth in accordance with worldly declarations. This understanding will cause science to be adaptive to the existing conditions. Science will only preserve and support the existing system. The further consequences of applying the instrumental ratios and the scientific ratios are what ultimately the reference's point becomes for critics of the critical theories of the Frankfurt School in the future.

\section{Max Weber Thought on Economic}

Max Weber is a classical sociological thinker who pays great attention to the economic system. Economy and Society and General Economic History are two of his most famous works on the economic system. However, Weber draws a clear line on how he sees the economy from a sociological perspective and does not get caught up in economic theories. For Weber, the economic system was born and influenced by other things outside the economic field. Weber defines social action as an act of the individual (actor) that has a subjective meaning to the individual but affects the other individual and expects the reaction of the other individual to arise. It can be seen in his book (Weber 1978): 
"Action insofar as the acting individual attaches a subjective meaning to his behavior...Action is "social" insofar as its subjective meaning takes account of the behavior of others and is thereby oriented in its course."

Max Weber most important work is The Protestant Ethic and the Spirit of Capitalism. In his theory, Max Weber explains the role and function of religion against the rise of modern capitalism. The modern capitalist system was only born in Western Europe (now is North America) and its development was greatly motivated by the spirit of capitalism. The spirit of capitalism is not the essence of capitalism as an economic system, but a mental attitude which allows modern capitalism. The spirit of capitalism is a rational and systematic way of seeking profit (Narwoko 2004).

Weber analysis of protestant ethics and its influence in promoting the growth of capitalism shows his understanding from the importance of religious beliefs as well as values in shaping the individual's motivational patterns as well as his economic activity. The influence of religion on the patterns of individual behavior and forms of social organization can also be seen in its comparative analysis of the great world religions. Weber also proposes an ideal type of analysis where it is possible to cope with specific events and to provide comparative analysis using common theoretical categories. The whole approach emphasizes that the ideal and material interests govern the actions of people, and the relationship between religious ideals and economic interests is actually interdependent. In other words, the relationship is mutual, including the interdependence between protestant and capitalism. In modern capitalist development, demanding for capital growth, demanding willingness to submit to systematic planning disciplines, working regularly in a work, and for future purposes (Swedberg 1996). 
DISCUSSION

Max Weber Thought and Its Relation to The Work Purposes and Ethics in Islam

Religion and work ethic have significant relevance as one of spiritual motivation toward additional value of goodness and charity for family and others. Religion moves in the spiritual dimension, whereas work or effort is worldly dimensioned to make a living.

History proves that religious thought is very influential for the development of material aspects, both political, economic, social, and cultural. In other words, there is a very significant relationship between the progress in thought (immaterial) and the progress in the material field. The spirit of capitalism also includes the work ethic which means that all the time that is not used to earn money is a waste. "Time is money" is the principle of the capitalists.

Profit-seeking entails the implication that any form of waste should be avoided, costs are suppressed and no capital is wasted. The calculation of income and expenditure is made carefully. However, it is not just a matter of how to do a successful business but an ethic or a special ethos in an effort to answer God's call. Ethos is not something that happens to humans. The desire to earn money is natural, but a special ethos that emphasizes systematic efforts to earn money through rational ways with underlying restrictions in the consumption cultivated and developed. This is what causes great economic development in the western world.

Islam is considered a class religion of warriors, has a tendency to feudal interests oriented toward social prestige, sultanistic and bureaucratic patrimonial, and has no spiritual preconditions for the growth of capitalism. Weber believes that Islamic teachings have an anti-intellectual attitude and are strongly opposed to knowledge, especially in technological knowledge. The strong reason for Weber to come to this conclusion is the economic practices of Muslims who do not support the process of capitalism in a comprehensive way. Similarly, Islamic sufistic practices that generally impress the "anti world or forget the world" attitude form as the basis of these conclusions (Abdullah 1993). 
Weber's thesis is less able to be accountable in reality, and even get rebutted from various researchers who want to see the realization between religion and work ethic. The inaccuracy of Weber's conclusion is suspected to be less serious and comprehensive in studying Islam, including other religions. In addition, Weber not only emerged as a fascinating European boy over the history of his civilization, he was also a follower of the intellectual tendencies of orientalism who tended to see Islam.

Putting aside the question of why Weber sees the above, it is clear that these views are both theologically and sociologically, hardly accepted by Muslims, or at least by observers who understand Islam honestly and well. Even by some orientalist any such views are difficult to accept. As like as Bryan S Tunner corrected and criticized Weber as well. In the view of Tunner, Islam is not a warlike warrior or warrior religion, but it stores teachings about luxurious living and high work ethos. He also said "he (Weber) was hopelessly incorrect in purely factual terms (S.Tunner 1974).”

He (Weber) misunderstood the truth. In this connection W.Montgomery Wa states that Islam is a religion of non-religious traders of the desert and not the religion of the peasants. The strong Islamic monotheism is closely related to experience. Man's lack of malignity in the desertness of the desert has been popular in the 19th century by Ernest Renan. The first people to be Muslim were not Bedouin people living in the desert, but people from trade puzzles in Mecca and the fertile farmland of Medina. A number of Arabs wrote their journey to China, where the oldest writings were written by Sulaiman merchants in 850 AD. In this case it is clear that the relationship between the two nations has been closely intertwined, since Chinese goods are also found in the inventory of Khalifah wealth and the exchange of trade ambassadors between the first Khalifah and the Chinese government (Wa 1972).

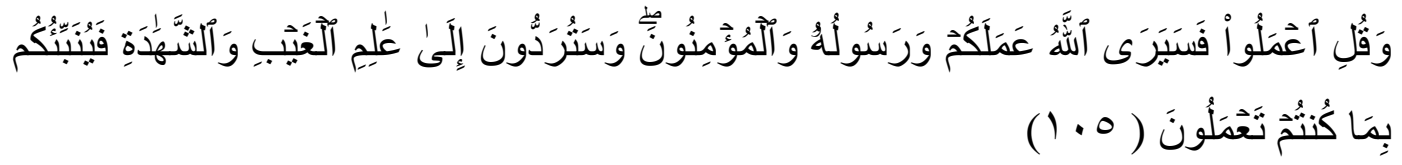


Translation: and say "do (as you will), for Allah will see your deeds, and (so, will) His Messenger and the believers. And you will be returned to the Knower of the unseen and the witnessed, and He will inform you of what you used to do." ${ }^{1}$

Asbabun nuzul of this verse is not explained directly. According to Lubabun Nuqul fii Asbabin Nuzul book, it is only explain the previous verse, verse 102. This book describes Abu Lubabah incident and five others who do not go to the war. The incident was narrated by Ibnu Abbas that Rasulullah SAW go to the war (as-Suyuthi 2009).

Then they reflect, regret it, and they say "we will be wretched. We are in a calm and serene place with women, while the Rasulullah SAW and the believers are in jihad. Then they swear, By Allah, we will bind our bodies in the mosque, and we will not release them unless Rasulullah SAW himself releases them."

After they swore, then they do what they say. However, not all of them were to freeze, there were three people who did not carry out their oath. After returning from the war, the Prophet asked, "who are the people bound on this pole?" There was someone who replied, "They are Abu Lubabah and his comrades who did not go to war. They swore they would not give up their ties unless Rasulullah SAW himself let them go." Then, Rasulullah SAW said, "I will not release them unless I am commanded (by Allah)." With this incident, Allah revealed the Surah At-Taubah verse 102, and then the Prophet released them and forgave them.

This verse according to M. Quraish Shihab aims to encourage mankind to be aware of themselves and to supervise their deeds, by reminding them that every good and bad deed has unbearable nature, and has the witnesses who know and see the essence, namely Rasulullah SAW, and the witnesses of the Muslims after Allah SWT. After that, Allah SWT will open the veil covering their eyes of those who do the deeds on the judgment day, thus they also know and see their own charity (Shihab 2002).

From the description of the interpretation, it can be said that mankind is commanded by God to always do work that is beneficial for oneself and for

${ }^{1}$ Q.S At-Taubah [09:105]. 
others, because all charities will be seen by Allah SWT, Rasulullah SAW, and the believers, and will be shown by Allah on the day of judgment then will get reward according to the deeds of his or her deeds in the earth. If the deeds are good it will be rewarded, and if the deeds are bad will receive the punishment (Suma 2015).

This verse basically commands everyone to work, including working in the economic field. All efforts, will surely be known by Allah SWT, Rasulullah SAW, and the believers as a whole. Every effort will certainly reap the rewards, and the right to give reward and punishment is Allah SWT. All and every action of a person, good or bad in the end is shown or displayed as it is (as-Suyuthi 2009).

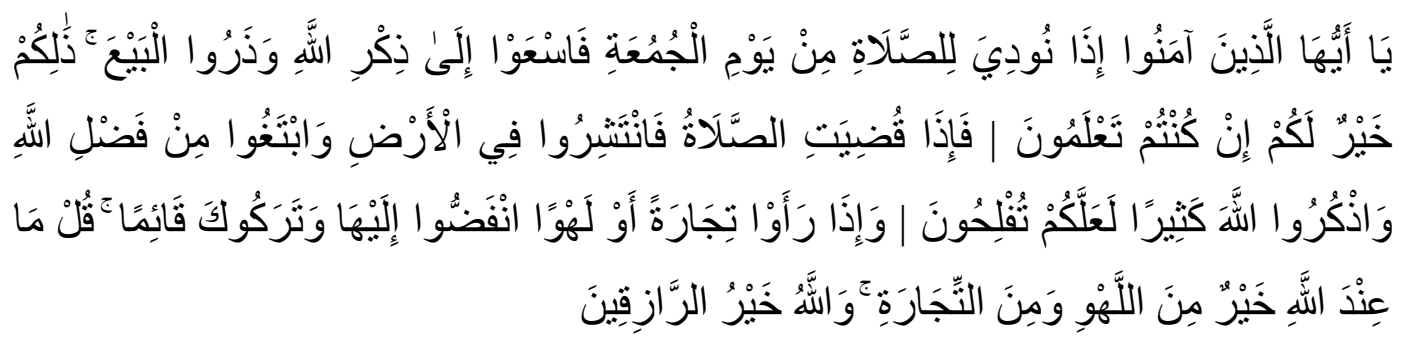

Translation: "O you who have believed, when (the adhan) is called for the prayer on the day of Jumu'ah (Friday), then proceed to the remembrance of Allah and leave trade. That is better for you, if you only knew. And when the prayer has been concluded, disperse within the land and seek from the bounty of Allah, and remember Allah often that you may succeed. But when they saw a transaction or a diversion, (O Muhammad), they rushed to it and left you standing. Say, "What is with Allah is better than diversion and a transaction, and Allah is the best of providers."2 (A Pro Bono Project 2016)

According to the narrative described by Jabir in Safwatut-Tafsir, that: "When Rasulullah SAW standing for sermon on Friday, suddenly the caravan (kafilah) come from Medina. So the companions of Rasulullah SAW headed for the caravan (kafilah) immediately, leaving only twelve people, Abu Bakr and Umar. So Allah sent down the verse, "And when they see commerce or game,

${ }^{2}$ Q.S. Al-Jumuah [62:09-11]. 
they disperse to go to this and they leave you standing (sermon) (Mu'ammal Hamidy 1987)."

According to some experts, one day Rasulullah SAW stood on the pulpit in order to give a Friday sermon. In the midst of the sermon, there was a trading caravan arrived from Syria (Syam), carrying merchandise in the form of food that was very tempting the inhabitants of Madinah who was being hit by hunger and goods became expensive. Their tradition, once the caravan arrives, they scream or whistle bells and others thing which imitate the joyful atmosphere. As soon as the caravan drew closer and closer, the residents of the mosque who were listening to the Friday sermon of Rasulullah SAW, were also unable to restrain themselves as they left Rasulullah SAW who remained standing in the pulpit. Hardly any worshipers left, except for only about 12 people. Jabir says I am one of those 12 people (Suma 2015).

It is also reinforced by the opinion of Abu Hayan narrated in tafsir alBahrul Muhith, that the cause until they disbanded because the people of Medina were in the famine season, and the price of goods was very high. So, when the caravan came with merchandise, it was according to their custom when the caravan entering the city was required to hit the drums and other sounds. That is when the caravan entered the city with its sounds then they broke up to watch it, while Rasulullah SAW was standing on the pulpit in which there were only twelve people left. With regard to the prohibition of buying and selling at the time of the Friday prayer execution described in Q.S Al-Jum'ah [62]: 9 "the Muslims should be more concerned with the hereafter than the life of the (temporal) world." Not long after this the verse above is relegated (Ibid).

Imam Al-Qurthubi opinion in the Tafsir Al-Qurthubi of QS Al-Jumu'ah [62]: 9-11, that: the forbidden time to transact that is; First, according to AdhDhahak, Hasan and Atha, after the sun slipped until the Friday prayer is over. Second, according to Syafi'i, from the call prayer (adzan) echoed when the imam will preach until the Friday prayers ended (Taufik Damas 2013).

Allah specializes the prohibition of buying and selling because buying and selling are an activity that are often preoccupied by people in the market. In this 
case, it should be understood that the person who is not required to attend the Friday prayer is not prohibited to do buying and selling.

From the explanation above, it can be concluded that the opinion of Imam Al-Qurthubi regarding the prohibition of sale and purchase transactions at Friday sermons is damaged and void because the time spent to conduct economic activities coincide with the implementation of the Friday prayers and can occupy yourself, thus that someone divert their obligations to the Allah SWT command, this prohibition also applies to the mukallaf because this prohibition is not in accordance with the QS Al-Jumu'ah verse [62]: 9. As expressed by Ibn Qudamah in Al Mughni tafsir, people who are not obliged to do Friday prayers such as traveler, children, woman and sick person, then they perform the dzuhur prayer (Qudamah 2007).

Furthermore, according to the view of M. Quraish Shihab above verse states: O believers, when the calling is called the call to prayer by anyone to do $d z u h u r$ prayer on Friday, then hasten the determination and step, do not laze or ignore it for go to dzikrullah to attend the Friday prayer and sermon, and leave buying and selling activities, that are all kinds of interactions in any forms and interests and all the things which can reduce the attention to the Friday ceremony. Such is the goodness that you must heed this command (Shihab 2002).

These verses specialize to the believers in order to do the Friday prayers when the call to prayer Friday echoed immediately. The use of word al-bai in this verse is the intent of covering all muamalah activities, not only trading in the narrow sense, but also any activity undertaken at the time, including primarily business activities, they must be abandoned it as soon as the call to prayer is spoken, unless there is an obstacle or syar'i excuse that causes a person to not perform the Friday prayer and replace it with the $d z u h u r$ prayer. Among them are the sick and the traveler (tiring travel and narrow time).

Nowadays, there are many activities which if left behind will harm and threaten many people or even the public interest. For example, security officers at certain posts that require security all the times; or certain factories with long-term operations, and if it is stopped for a moment, it is strongly suspected to suffer 
huge losses. For such officers, it is permissible to not perform the Friday prayers and remain obliged to perform the dzuhur prayer.

According to Quraish Shihab, there are lessons that can be drawn above verse (Shihab 2002):

a) This is a duty for every man to abandon all activities, since adzan as the sign of Friday prayer.

b) Prayer and sermon Friday are part of $d z i k r$, therefore the above verse using the word dzikrullah.

c) Rushing to the mosque in the context of Friday prayers is not by running or running fast, especially there is the command of Rasulullah SAW which states: "When the prayer will be executed (iqamat), then do not go there by walking quickly $\left(s a^{\prime} i\right)$, but attend with sakinah (serenity and full of authority). The part of prayer that you find, do it and the left do after it perfectly."(Narrated by Bukhari Muslim)

d) Friday Prayer is considered as a substitute for $d z u h u r$ prayer, for who has performed Friday prayer is not mandatory to do $d z u h u r$ prayer again. Two sermons at the Friday prayer are judged to replace two raka'at in dzuhur prayer.

e) The above verse shows to the believers which may include men and women, whether those who live in their country of residence or the traveler. But Rasulullah SAW explains "Friday Prayer is mandatory for every Muslim to be carried out in congregation, except for four groups (group), namely slave, women, children, and the sick.

f) Although women are not required to perform the Friday prayers, but if they do it with other pilgrims then their prayer is valid and they no need to pray dzuhur.

Furthermore, from the above paragraph according to Prof. Amin Suma, istinbat on this verse can be summed up in several points:

a) Basically, Allah does not forbid believers to engage in worldly activities (muamalah) on Friday, as long as they still perform the obligatory of Friday prayers, except for those who have syar'i reasons. 
b) The limit of tolerance of business or other activities on Friday, until the adzan to Friday prayer. When Friday adzan is echoed by mu'adzin, all the worldly activities symbolized by economic business, must be abandoned, not to mention the activities of business that lure material profits.

c) After performing the Friday prayers, believers are allowed to rescattered on earth to perform various activities in the world. This implies the principle of balance between worship on the one hand and the other's muamalah (Suma 2015).

Based on the Max Weber's Theory on the objectives of rationality and the value of rationality, Islam lays more on the value of rationality, but it does not mean that Islam agrees with Max Weber's theory. Islam has its own purpose of any activities and works. In general, the purpose of work is to earn money or a livelihood in fulfilling its integrity to survive or live its life. In Islam, work can be a life support and also as a means of worshiping Allah SWT. Furthermore, the goals of working in Islam are (Ya'qub 2001):

a) Working for the pleasure of Allah SWT

The purpose of working in Islam is not only to fulfill the instinct of living for the sake of the stomach, but Islam also provides a noble philosophical direction, a noble purpose, the ideal goal is ta'abbud, seeking the pleasure of Allah SWT. All efforts and activities of $m u^{\prime m i n}$ both world and hereafter pattern focused on a focal point of the philosophy of Muslim life essentially - the pleasure of Allah SWT.

b) Working to fulfill the life needs

We live in this world has a number of diverse needs which are divided into three levels:

1. Basic needs

2. Secondary needs

3. Tertiary or luxurious needs 
In the order of the human life livings, the primary needs are urgent that should not be ignored. Second and third needs can still be deferred, but primary needs must be fulfilled as soon as possible.

c) Working to fulfill a family's life

Islam commands a halal food and wears a good dress covering the aurat which can be manifested through work, and responsibility to men, husbands or heads of households in fulfilling the family's needs. The husband or head of the household is responsible for the household harmony. Such obligations and responsibilities create consequences for the husband. Functions and responsibilities which require him to get up, move and work diligently.

d) Working for charity (alms)

Between the purposes of work is that the results of his or her work can be used to perform one command; charity. The beautiful of Islamic teaching always encourage people to continue doing ihsan wherever and whenever to human.

e) Working for worship interests

In addition, a relationship between the industry and charity (ihsaniah), then in the field of worship also has a clear relationship because the activities of industry support the worship to Allah SWT.

f) Working to reject crime

Among the ideal goals of working is rejecting some of the possible crime which can happen to an unemployed person. Working means eliminating one of the bad attributes and attitudes of laziness and unemployment, because of work opportunity covering the negative circumstances.

Based on Surah At-Taubah verse 105 and Surah Al-Jumuah verses 9-11 which command work in Islam and Allah strongly encourages his people to work because the position of work in Islam is occupying in a very important position because of work as a support to the fulfill the human needs. Islam puts the position of work in a very noble place that is classified on fi sabilillah. This is 
reflected in the words of Rasullulah SAW narrated by Thabrani from his book Toto Tasmara which means: "It is narrated from Ka'ab bin Umrah: There is someone walking past the place of Rasullah SAW that the man is working very diligently and agile. The Companions then said: "Oh Rasullulah, if the word works like that kind of man can be classified fi sabillilah, it would be nice". Then Rasullulah said: "If he works to defend his elderly parents, he is fi sabillilah. If he works for his own sake in order not to beg, he is fi sabilillah (Narrated by Thabrani).

From that hadits it can be taken an i'tibar that the position of work in Islam is placed in a very position. This is as the hadith of Rasulullah SAW explains the importance of working in earnest then this is equated with jihad fi sabillilah. Fighting in the way of Allah SWT because by working it will improve the standard of living and not become beggars. By working also, we can live the Islamic magnificience by helping the poor with the treasure through the way of zakat, alms, infak, and others.

Islam also has its own ethics on the economic activity. Work ethic according to Musa Asy'arie, character and quality of life of human, moral, spiritual and an esthetic styles as well as their inner aura. It is am essential attitude towards themselves and their world are mirrored in the real world. Work ethic can be explicated as an attitude or behavior and a look towards the work, work habits; traits or attributes about the workings of that someone, a group of people or nation, is also part of the values (value system) (Asy'arie 1997).

Many Islamic scholars said that the Islamic work ethics are; (1) hard work; (2) discipline; (3) honest; (4) efficient; (5) visionary; (6) rational; (7) cooperation; and (8) of achievement (Najib 2015). All the muslims around the world should not be worry of any things because Islam does not view the failure according to the material. As like as the hadits said in Muslim number $4678:^{3}$

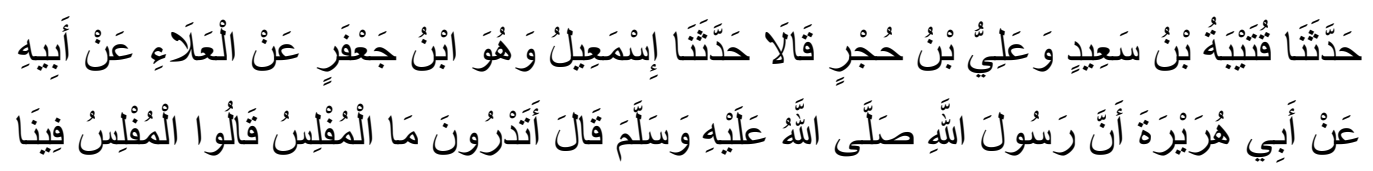

${ }^{3}$ Lidwa Pusaka i-Software, Kitab Muslim, No. 4678 


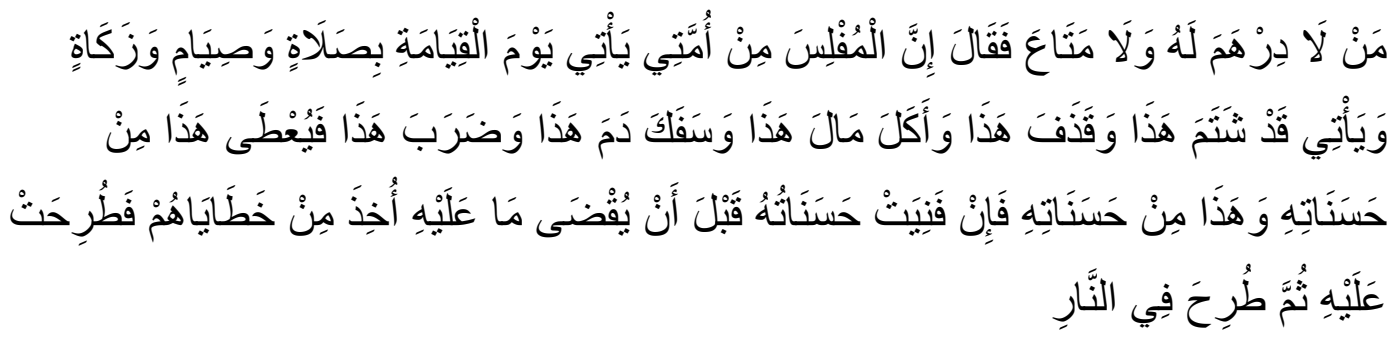

After reading the shahih hadits ${ }^{4}$ above, we need to worry and reflect to each of us, whether during this action and our speech often sharply hurt others? Even accusing him of various allegations (which have not been proven explicitly) until he was decimated. No wonder we are afraid of the bankruptcy of ourselves in the hereafter, because if it goes bankrupt in the hereafter nothing can help us from the threat of hell fire.

Al-Imam Abu Zakariyaa An-nawawiy rahimahullah when explaining the above hadith, he said: "This hadith shows the true nature of a bankrupt person. As for a person who has no wealth or little wealth and man calls the circumstances of such a person is a bankrupt person, then this is not the true nature because this situation will disappear and stop with the death of that person or may be stalled with the splendor of sustenance after he experiencing such a difficult situation in his life. Thus, the essence of the bankrupt is as mentioned in the above hadith, the perished with perfect destruction, and the lost (the reward) with slow reduction, the rewards of his good for the victim of his destruction. When the reward of his good deeds has been taken from their evil deeds and inflicted on him, he is thrown into the fire of hell. So perfect his loss, his destruction and his bankruptcy (Almanhaj).

In one hand, muslim has their own ethics understanding namely al-Qur'an and hadits as like as in the previous pragraph mention above. But, it can be avoided that Max Weber thought has a right side to be examined and compared.

\footnotetext{
${ }^{4}$ According to Takhrij prosess from Lidwa Pusaka i-Software by the author
} 
Moreover, the empirical story from Max Weber has influenced the economic history in the world in which every universities talks about it.

\section{Max Weber Thought and Its Relation to The Muslim Ethics in Islamic Banking}

According to the rationality types by Max Weber, the value of rationality is the closest theory with the theory in Islamic perspective. Talking about Muslim ethics in spreading Islamic economic industry out to others - particularly for Islamic banking industry has their own ethics value. From 2010 to 2013, Bank Mu'amalat Indonesia (BMI) is the Islamic public bank which takes the first rank in communicating the information about Islamic ethics identity, while in the second rank is Bank Syari'ah Mandiri (BSM), except in 2011, BSM and BMI have a same value of ethics identity index (Fauziyah \& Siswantoro 2016).

Sharia banking businessmen must uphold the value of religiosity in work, because Islamic banks will be one of the ambasador in implementing Islamic values. If Islamic value is not so strong in Islamic banking industry, it will affect its customers indirectly.

\section{CONCLUSION}

\section{Conclusion}

Weber has explored all written history, from the Ancient Greeks to the beginning of the Hindu period, from the Old Testament apostles to the Confucian poet, from the Eastern economic organization near the earliest civilizations to medieval western trade, and from the origins of continental law to emerging comparative analysis of the emergence of the Modern state. Human behavior is the choice of man himself who in influenced by the thinkers it has. If one consistently associates each decision as its choice with a certain ideological benchmark, this mindset then colors one's behavior.

A person who constantly associates his thoughts with a capitalist ideology will give birth to a capitalist mindset and if done will elicit capitalistic behavior. A 
person who often associates his thoughts with a socialist ideology will produce a socialist mindset and will influence his socialistic behavior. Similarly, making Islam a benchmark will give birth to an Islamic mindset and if practiced will lead to an Islamic behavior pattern.

Western theories do not always contradict to Islamic principles. One of them is the value of rationality by Max Weber. In fact, the contemporary philosopher's thought must be compared with Islamic values so that the red thread can be taken to be implemented in life, especially in the economic activities of Islam. Islam has a work purposes that not only pursues the world, but also the hereafter. Including ethics in work, Islam does not know bankrupt as bankrupt as a lack of treasures of the world, but the reduced of reward when in yaumul akhir. Max Weber also said that economic activity and religion are cannot be separated as like as Islamic perspective in which world interest cannot be parted with religion. If it is happen, there will be a clash.

\section{Recomendation}

There are sore recomendations to be studied more:

1. The activists or practitioners of Islamic economics should be open to western knowledge without forgetting the history that exists in Islam.

2. The rsearchers should be more talking about comparisons of western philosophical thought and theory in Islam because many facts reversed its history.

Muslims should has a better understanding about their own religion, especially in spreading Islamic economic values out in everyday life. 


\section{REFERENCES}

A Pro Bono Project. 2016. https://quran.com.

Abdullah, Taufiq. Tesis Weber dan Islam di Indonesia dalam Agama, Etos Kerja dan Perkembangan Ekonomi. Jakarta: LP3ES, 1993.

Admin. Tafsir Surah Hud Ayat 61. May 28, 2015. http://www.ibnukatsironline.com/2015/05/tafsir-surat-hud-ayat-61.html (accessed June 6, 2018).

Admin, and The University of Kent. The Most Influencial Economist of All The Time.

2018. https://www.thecompleteuniversityguide.co.uk/courses/economics/the-tenmost-influential-economists-of-all-time/?entry $=10 \quad$ (accessed June 7, 2018).

Al-Ghazali, Hujjah Al-Islam Abu Hamid. Al-Tibr Al-Masbuk fi Nashihah AlMuluk. Beirut: Dar Al Kutub Al Ilmiyah, 1988.

Al-Ghazali, Hujjah Al-Islam Al-Imam Muhammad Abu Hamid. Al-Iqtishad fi AlI'tiqad. Damaskus: Dar Qutaiba, 2003.

Al-Ghazali, Imam Abu Hamid. Ihya' Ulum Al-din. Mesir: Maktabah Al-Syuruq Al-Daulah, n.d.

Almanhaj. n.d. https://almanhaj.or.id/2714-jika-seseorang-tertimpa-pailit.html (accessed May 23, 2018).

Ashimi, Tijani Ahmad. "Islamic Civilization: Factors Behind Its Glory and Decline." International Journal of Business, Economics and Law IX, no. 5 (April 2016): 183-184.

as-Suyuthi, Jalaluddin. Lubabun Nuqul fii Asbaabin Nuzul. Jakarta: Gema Insani, 2009.

Asy'arie, Musa. Etos Kerja dan Pemberdayaan Ekonomi Umat Islam. Yogyakarta: Lesfi, 1997.

Crossman, Ashley. "Max Weber Biography”. Decembar 31, 2017. https://www.thoughtco.com/max-weber-3026495/.

Essa, Ahmed, and Othman Ali. Studies in Islamic Civilization The Muslim Contribution to The Renaissance. United State: The International Institute of Islamic Thought (IIIT), 2012.

Fauziyah, Yunika, and Dodik Siswantoro. "Analisis Pengungkapan Identitas Etika Islam dan Kinerja Keuangan Perbankan Syariah di Indonesia." Simposium Nasional Akuntansi XIX. Lampung, 2016. 1-19. 
Herdiansyah, Haris. Metodologi Penelitian Kualitatif untuk Ilmu-ilmu Sosial. Jakarta: Salemba Humanika, 2010.

i-Software, Lidwa Pusaka. Kitab Muslim, No. 4678. n.d.

Kalberg, Stephen. "Max Weber's Types of Rationality: Cornerstones for the Analysis of Rationalization Processes in History." The American Journal of Sociology, 1980: 1145-1179.

Karim, Adiwarman Azwar. Sejarah Pemikiran Ekonomi Islam. 2004: PT Raja Grafindo Persada, Jakarta.

Kurdi, and dkk. Hermeneutika Al-Qur'an dan Hadis. Yogyakarta: eLSAQ Press, 2010.

Mu'ammal Hamidy, dkk. Tafsir Ayat Ahkam as-Shabuni. Surabaya: PT Bina Ilmu, 1987.

Najib, Aan. "The Value of Work Ethic in the Qur'an Surah Saba'." International Journal of Humanities and Social Science, 2015: 160.

Narwoko, J. Dwi. Sosiologi, Teks Pengantar \& Terapan. Jakarta: Prenada, 2004.

Noorkholis. Max Weber Sosiologi. Yogyakarta: Pustaka Pelajar, 2006.

Nugroho, Irham. "Positivisme Auguste Comte: Analisa Epistemologis dan Nilai Etisnya Terhadap Sains." Jurnal Cakrawala, 2016: 2.

Qudamah, Ibnu. Al Mughni. Jakata: Pustaka Azzam, 2007.

Ritzer, George, and Douglas J. Goodmman. Teori Sosiologi. Yogyakarta: Kreasi Wacana, 2003.

S.Tunner, Bryan. Weber and Islam: A Critical Study. London: Routledge \& Keagan Paul, 1974.

Saleh, Abdul Mun'im. Madzhab Syafi'i; Kajian Konsep Al Mashlahah. Yogyakarta: Ittiqa Press, 2001.

Santoso, Listiyono, and dkk. Epistemologi Kiri. Yogyakarta: Ar Ruzz Media, 2007.

Shihab, M. Quraish. Tafsir Al- Mishbah Jilid 2 "Pesan, Kesan dan Keserasian Alquran. Jakarta: Lentera Hati, 2002.

-. Tafsir Al- Mishbah Jilid 2 "Pesan, Kesan dan Keserasian Alquran". Jakarta: Lentera Hati, 2002.

Sjadzali, Munawir. Islam dan Tata Negara: Ajaran, Sejarah dan Pemikiran. Jakarta: UI Press, 1990.

Soekanto, Soerjono. Sosiologi Suatu Pengantar. Jakarta: Rajawali Press, 2014.

Sou'yb, Joesoef. Sejarah Daulat Abbasiah III. Jakarta: Bulan Bintang, 1978. 
Suma, Muhammad Amin. Tafsir Ayat Ekonomi: Teks, Terjemah, dan Tafsir. Jakarta: Amzah, 2015.

Swedberg, Rkbard. Max Weber's Vision of Economics. Sweden: Stockholm University, 1996.

Syaikh, Dr 'Abdullah bin Muhammad bin 'Abdurrahman bin Ishaq Alu. Tafsir Ibnu Katsir. Translated by M. Abdul Ghoffar E.M. Bogor: Pustaka Imam Asy-Syafi'i, 2004.

Tasmara, Toto. Membudayakan Etos Kerja yang Islami. n.d.

Taufik Damas, dkk. Tafsir Jalalain Perkata. Jakarta Timur: PT Suara Agung, 2013.

Wa, W.Montogomery. The Influence of Islam on Medieval Europe. England: Edinburgh University Press, 1972.

Weber, Max. Economy and Society. London: University of California, 1978.

Ya'qub, Hamzah. Etos Kerja dalam Islam (Petunjuk Pekerjaan yang Halal dan Haram dalam Syariat Islam). Yogyakarta: CV Pedoman Ilmu, 2001. 